\title{
Phosphoserine phosphatase deficiency in a patient with Williams syndrome
}

\author{
Jaak Jaeken, Michel Detheux, Jean-Pierre Fryns, Jean-François Collet, Philippe Alliet, \\ Emile Van Schaftingen
}

defect in the last step of serine biosynthesis, namely that catalysed by 3-phosphoserine phosphatase.

Decreased serine levels were found plasma and cerebrospinal fluid (CSF) of a boy with pre- and postnatal growth retardation, moderate psychomotor retardation, and facial dysmorphism suggestive of Williams syndrome. Fluorescence in situ hybridisation with an elastin gene probe indicated the presence of a submicroscopic 7q11.23 deletion, confirming this diagnosis. Further investigation showed that the phosphoserine phosphatase (EC 3.1.3.3.) activity in lymphoblasts and fibroblasts amounted to about $25 \%$ of normal values. Oral serine normalised the plasma and CSF levels of this amino acid and seemed to have some clinical effect. These data suggest that the elastin gene and the phosphoserine phosphatase gene might be closely linked. This seems to be the first report of phosphoserine phosphatase deficiency. ( $\mathcal{}$ Med Genet 1997;34:594-596)

Keywords: chromosome 7; elastin; phosphoserine phosphatase; Williams syndrome

Department of

Paediatrics, University Hospital Gasthuisberg, University of Leuven, Herestraat 49, B-3000 Leuven, Belgium J Jaeken

Laboratory of Physiological

Chemistry, Institute of Cellular and Molecular Pathology, Brussels,

Belgium

$M$ Detheux

J-F Collet

E Van Schaftingen

Department of Human Genetics, University of Leuven, Leuven,

Belgium

J-P Fryns

Virga Jesse Hospital, Hasselt, Belgium P Alliet

Correspondence to: Dr Jaeken.

Received 11 July 1996 Revised version accepted for publication 19 February 1997
Serine is a non-essential, key amino acid, synthesised de novo from 3-phosphoglycerate, a glycolytic intermediate. As shown in fig 1, the latter is converted to serine through the successive action of 3-phosphoglycerate dehydrogenase (EC 1.1.1.95), 3-phosphoserine aminotransferase (EC 2.6.1.52), and 3-phosphoserine phosphatase (EC 3.1.3.3.). ${ }^{1-3}$ This amino acid can also be synthesised from glycine. Serine is not only a building block for protein synthesis but also a precursor of a number of compounds including amino acids (glycine and cysteine), phospholipids (phosphatidylserine and sphingomyelin), and glycolipids. It is also a major source of methylene tetrahydrofolate and of other one carbon donors required for the synthesis of purines and thymidine. ${ }^{4}$ We previously reported decreased serine levels in the cerebrospinal fluid of two brothers with congenital microcephaly, profound psychomotor retardation, epilepsy, and growth retardation. Fibroblasts of both patients showed decreased levels of 3-phosphoglycerate dehydrogenase. ${ }^{5}$ In this paper we report on a boy with Williams syndrome and with decreased levels of serine in plasma and CSF. It was found that this patient, in addition to a defect in the elastin locus typical of Williams syndrome, ${ }^{6-9}$ had a partial

\section{Patient and methods}

The patient, a Belgian boy, was born by caesarian section after a 37 week pregnancy, with birth weight $1760 \mathrm{~g}$, length $42.5 \mathrm{~cm}$, and head circumference $30 \mathrm{~cm}$. He had early feeding difficulties associated with gastro-oesophageal reflux and oesophagitis. He also had facial features suggestive of Williams syndrome including puffy eyelids, broad forehead, bitemporal narrowing, wide mouth, full cheeks, and micrognathia. There was also grade II hypospadias. Length and weight evolved approximately parallel with, and below, the 3 rd centile (at 22 months, length was $75 \mathrm{~cm}$ (3rd centile $=80 \mathrm{~cm}$ ) and weight $8.4 \mathrm{~kg}$ (3rd centile $=10 \mathrm{~kg}$ )) while the head showed a slight catch up growth before the age of 4 months and between the ages of 12 and 22 months (43.5 $\mathrm{cm}$ at 1 year, $3 \mathrm{rd}$ centile $=45 \mathrm{~cm}$ and $46 \mathrm{~cm}$ at 22 months, 3 rd centile $=46.6 \mathrm{~cm}$ ). Psychomotor development was slow. Plasma amino acid analysis by ion exchange chromatography and fluorescence detection showed decreased to low-normal fasting serine levels $(53-80 \mu \mathrm{mol} / \mathrm{l}$, $\mathrm{n}=4$ between the ages of 5 and 12 months; normal range 70-187). One to two hours after feeding, serine levels were normal. CSF serine was decreased $(18 \mu \mathrm{mol} / 1$ at the age of 1 year; control range 27-57). Plasma and CSF phosphoserine and glycine levels were normal.

Chromosome studies were performed on a peripheral blood lymphocyte culture with G banding and fluorescent in situ hybridisation using the elastin Williams syndrome chromosome region (WSCR) probe, with D7S42 chromosome control probe.

Oral L-serine was given to the patient from the age of 1 year up to the present age of 22 months. The initial dosage of $200 \mathrm{mg} / \mathrm{kg}$ per day was increased to $300 \mathrm{mg} / \mathrm{kg}$ per day at the age of 15 months (divided into three doses per day).

Serine biosynthesis was investigated in fibroblasts and lymphoblasts. The source of reagents and the enzymatic assays have been described elsewhere. ${ }^{5}$ Phosphoserine phosphatase was also assayed through the release of $\left.{ }^{32} \mathrm{P}\right] \mathrm{Pi}$ from $\left[{ }^{32} \mathrm{P}\right]$ phosphoserine. The assay mixture contained $25 \mathrm{mmol} / \mathrm{l}$ Mes buffer, $\mathrm{pH}$ $6.5,0.1 \mathrm{mmol} / 1$ phosphoserine, $20000 \mathrm{cpm}$ $\left[{ }^{32} \mathrm{P}\right]$ phosphoserine, $1 \mathrm{mmol} / 1 \mathrm{MgCl}_{2}, 1 \mathrm{mmol} / 1$ di-thiothreitol, and $5 \mu \mathrm{l}$ of extract in a final 


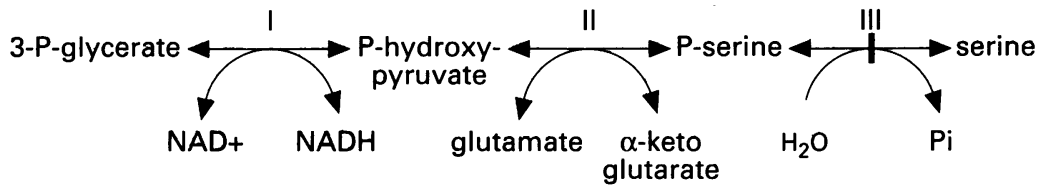

Figure 1 The pathway of de novo serine biosynthesis. I: 3-phosphoglycerate dehydrogenase; II: 3-phosphoserine aminotransferase; III: 3-phosphoserine phosphatase. Vertical block denotes the enzymatic defect in the patient.

volume of $0.1 \mathrm{ml}$. The incubations were carried out at $30^{\circ} \mathrm{C}$ for 10 to 30 minutes and were arrested by addition of $250 \mu \mathrm{l}$ of $5 \%$ thrichloroacetic acid and $5 \mu \mathrm{l}$ of $10 \mathrm{mmol} / \mathrm{l} \mathrm{Pi}$. $\left.{ }^{32} \mathrm{P}\right] \mathrm{Pi}$ was extracted according to McClard. ${ }^{10}$ Fibroblasts (passages 3-11) were cultured as previously described. ${ }^{5}$ Lymphoblasts (passages 2-5) were cultured in Iscove's Modified Eagle Medium supplemented with $10 \%$ fetal calf serum, GlutaMAX I, $0.24 \mathrm{mmol} / 1$ asparagine, $0.55 \mathrm{mmol} / 1$ arginine, $100 \mathrm{U} / \mathrm{ml}$ penicillin, and $100 \mu \mathrm{g} / \mathrm{ml}$ streptomycin. Cells in suspension were collected by centrifugation $(1000 \times g, 10$ minutes $)$ and washed twice in $\mathrm{Mg}^{2+} / \mathrm{Ca}^{2+}$ free phosphate buffered saline. Cell pellets were either disrupted immediately for enzyme assays or stored at $-80^{\circ} \mathrm{C}$ for up to three months without loss of activity. Cell extracts were prepared as previously described. ${ }^{5}$

\section{Results}

Prometaphase chromosome studies showed an apparently normal 46,XY G banded karyotype but fluorescent in situ hybridisation showed a submicroscopic 7 q11.23 deletion in all 10 cells examined.

During treatment with oral serine, a slight catch up of head growth was noted; whereas before treatment, from the ages of 4 to 12 months, head circumference remained at 1.5 $\mathrm{cm}$ below the 3 rd centile, after 10 months of oral serine, head circumference was only 0.6 $\mathrm{cm}$ below the 3 rd centile. There was no catching up of length and weight. Under treatment with serine at $200 \mathrm{mg} / \mathrm{kg}$ per day (divided into three doses) fasting CSF serine level was 23 $\mu \mathrm{mol} / \mathrm{l}$ (control range 27-57) before the morning serine dose, while under $300 \mathrm{mg} / \mathrm{kg}$ per day a low normal value of $29 \mu \mathrm{mol} / 1$ was obtained.

Activity of 3-phosphoserine phosphatase amounted to only about $25 \%$ of the activity of the mean control value both in fibroblasts $(0.36$ and $0.50 \mathrm{mU} / \mathrm{mg}$ protein; controls $(\mathrm{n}=14)$, mean $1.67, \mathrm{SD} 0.18)$ and in lymphoblasts $(0.35$ and $0.39 \mathrm{mU} / \mathrm{mg}$ protein; controls $(\mathrm{n}=11)$, mean 1.34, SD 0.09), whereas the activities of 3-phosphoglycerate dehydrogenase and of 3-phosphoserine aminotransferase were normal (table 1). The $\mathrm{Km}$ of phosphoserine

Table 1 Activities of the enzymes of the serine biosynthesis in fibroblasts and lymphoblasts of the patient and controls ( $x[S D] \mathrm{mU} / \mathrm{mg}$ protein)

\begin{tabular}{llll}
\hline & $\begin{array}{l}\text { 3-phosphoglycerate } \\
\text { dehydrogenase }\end{array}$ & $\begin{array}{l}\text { 3-phosphoserine } \\
\text { aminotransferase }\end{array}$ & $\begin{array}{l}\text { 3-phosphoserine } \\
\text { phosphatase }\end{array}$ \\
\hline $\begin{array}{l}\text { Fibroblasts } \\
\text { Controls }\end{array}$ & $29.49[2.65](15)$ & $1.98[0.28](9)$ & $1.67[0.18](14)$ \\
$\begin{array}{l}\text { Patient } \\
\text { Lymphoblasts }\end{array}$ & $26.28[1.36](3)$ & $3.14[0.21](3)$ & $0.36 ; 0.50$ \\
$\quad \begin{array}{ll}\text { Controls } \\
\text { Patient }\end{array}$ & ND & $0.88[0.23](11)$ & $1.34[0.09](11)$ \\
\hline
\end{tabular}

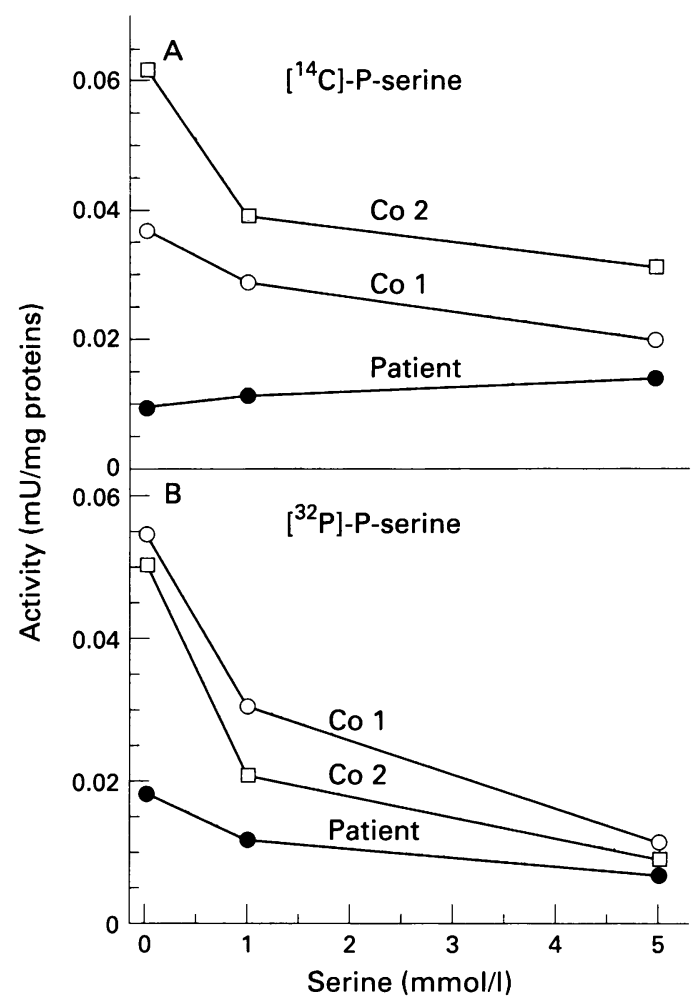

Figure 2 Effect of serine on phosphoserine phosphatase activity in extracts of lymphoblasts from two controls and the patient. The enzymatic activity was measured in lymphoblast extracts by the release of radiolabelled serine (A) or $\mathrm{Pi}(B)$ from $\left[{ }^{4} \mathrm{C}\right]$ or $\left[{ }^{32} \mathrm{P}\right]$ phosphoserine.

phosphatase (determined on double reciprocal plots) was about $10 \mu \mathrm{mol} / \mathrm{l}$ both in the patient and in the controls. There was, however, a significant difference in the inhibition exerted by serine. The release of $\left[{ }^{14} \mathrm{C}\right]$ serine from $\left[{ }^{14} \mathrm{C}\right]$ serine 3-phosphate was partly inhibited by cold serine when it was catalysed by the enzyme from controls but not when it was catalysed by the enzyme of the patient (fig 2A). When the enzymatic activity was measured through the liberation of $\left[{ }^{32} \mathrm{P}\right] \mathrm{Pi}$ from $\left[{ }^{32} \mathrm{P}\right]$ phosphoserine, the activity was inhibited in all cases, though relatively less with the patient's enzyme than with the enzyme from controls (fig $2 \mathrm{~B}$ ).

\section{Discussion}

The present patient had moderately but significantly decreased levels of serine in CSF and low to low-normal fasting levels of plasma serine. These findings suggested a defect in the biosynthesis of serine. This was confirmed by the finding in cells of the patient of markedly decreased activity of 3-phosphoserine phosphatase, the enzyme catalysing the third and rate limiting step of serine synthesis from the glycolytic intermediate, 3-phosphoglycerate (fig 1). Since this step is rate limiting for the pathway, ${ }^{11-13}$ the decrease in phosphoserine phosphatase activity is expected to result in a commensurate decrease in the formation of this amino acid. However, the clinical picture was suggestive of Williams syndrome. This diagnosis was substantiated by finding a deletion in the elastin gene region of chromosome 7 (7q11.23)..$^{9}$ The association of Williams syndrome and 3-phosphoserine phosphatase deficiency in the same patient 
suggests a relationship between them, the most probable being that the 3-phosphoserine phosphatase gene is closely linked to the elastin gene and therefore involved in the deletion. Studies with interspecific cell hybrids have indeed indicated that human 3-phosphoserine phosphatase is encoded by chromosome $7 .^{14}$ The more precise assignment to region $7 \mathrm{p} 15^{1516}$ could argue against a deletion involving both genes. It should be noted, however, that this assignment was based on gene dosage studies ${ }^{15} 16$ and that these have to be interpreted with caution since the activity of phosphoserine phosphatase was found by Minelli et al ${ }^{17}$ not to be reduced in cells with monosomy 7 .

The fact that the enzymatic activity is reduced by more than $50 \%$ (actually to about $25 \%$ ) and the finding that it has modified kinetic properties compared to the controls indicate that the second copy of the gene is mutated. An alternative explanation would be that the residual activity is contributed by the product of a different gene. Moro-Furlani et $a l^{12}$ found, however, that in most tissues phosphoserine phosphatase consisted of one single major isozyme; the minor isozymes found in some samples of postmortem tissue were probably the result of post-translational modification.

Whether the moderate decrease of serine levels in the present patient has clinical consequences remains to be determined. That there might be an effect is suggested by the slight catch up of the head growth. This treatment was able to normalise CSF and probably also brain serine levels. As previously pointed out for 3-phosphoglycerate dehydrogenase deficiency, ${ }^{5}$ this synthesis defect is unusual among the amino acid defects, which, in the large majority, are catabolic defects. ${ }^{18}$

We would like to thank Mrs G Berghenouse for competen technical help. This work was supported by the National Fund for Scientific Research (grants 3.0115.94 and 3.4596.92), by the Actions de Recherche Concertées, and by the Belgian Federal Service for Scientific, Technical and Cultural Affairs.

1 Knox WE, Herzfeld A, Hudson J. Phosphoserine phosphatase distribution in normal and neoplastic rat tissues. Arch Biochem Biophys 1969;132:397-403.

2 Snell K. Enzymes of serine metabolism in normal and neoplastic rat tissues. Biochim Biophys Acta 1985;843:276-81.

3 Snell $\mathrm{K}$. The duality of pathways for serine biosynthesis is a fallacy. Trends Biochem Sci 1986;11:241-3.

4 Snell K. Enzymes of serine metabolism in normal, developing and neoplastic rat tissues. Adv Enzyme Regul 1983;22: $325-400$

5 Jaeken J, Detheux M, Van Maldergem L, Carchon H, Foulon $M$, Van Schaftingen $M$. 3-phosphoglycerate dehydroge nase deficiency: an inborn error of serine biosynthesis. Aich Dis Child 1996;74:542-5.

6 Williams JCP, Barratt-Boyes BG, Lowe JB. Supravalvular aortic stenosis. Circulation 1961;24:1311-18.

7 Beuren AJ, Apitz J, Harmjanz O. Supravalvular aortic stenosis in association with mental retardation and a certain facial appearance. Circulation 1962;26:1325-40.

8 Morris CA, Demsey SA, Leonard CO, Dilts C, Blackburn BL. Natural history of Williams syndrome: physical characteristics. F Pediatr 1988;113:318-26.

9 Ewart AK, Morris CA, Atkinson D, et al. Hemizygosity at the elastin locus in a developmental disorder, Williams syndrome. Nat Genet 1993:5:11-16.

10 McClard RW. Synthesis and purification of $\left[1^{32} \mathrm{P}\right]$ fructose1,6-bisphosphate with high specific radioactivity. Anal Biochem 1979;96:500-3.

11 Borkenhagen LF, Kennedy EP. The enzymatic exchange of L-serine with O-phospho-L-serine catalyzed by a specific phosphatase. F Biol Chem 1959;234:849-53.

12 Moro-Furlani AM, Turner VS, Hopkinson DA. Genetical and biochemical studies on human phosphoserine phosphatase. Ann Hum Genet 1980;43:323-33.

13 Lund K, Merrill DK, Guynn RW. The reactions of the phosphorylated pathway of L-serine biosynthesis: thermodynamic relationships in rabbit liver in vivo. Arch Biochem Biophys 1985;237:186-96.

14 Sparkes RS, Mohandas T, Sparkes MC. The human phosphoserine phosphatase gene (PSP) is mapped to chromosome 7 by somatic cell genetic analysis. Cytogenet Cell Genet 1983;35:70-1.

15 Koch GA, Eddy RL, Haley LL, Byers MG, McAvoy M, Shows TB. Assignment of the human phosphoserine phosShows TB. Assignment of the human phosphoserine phosphatase gene (PSP) to the pter $\rightarrow \mathrm{q} 22$ region
some 7. Cytogenet Cell Genet 1983;35:67-9.

16 Novelli G, Dallapiccola B. Gene dosage studies regionally assign the phosphoserine phosphatase gene to 7 p15.1 or 2 . Ann Genet (Paris) 1988;31:195-6.

17 Minelli A, Piantanida M, Maserati E, Campagnoli E, Pasquali F, Danesino C. Gene dosage effect in acquired monosomy 7. Genes Chrom Cancer 1990;1:216-20.

18 Scriver CR, Beaudet AL, Sly WS, Valle D, eds. The metabolic and molecular bases of inherited disease. New York: McGrawHill, 1995:1015-368. 